\title{
Preneoplastic Change
}

National Cancer Institute

\section{Source}

National Cancer Institute. Preneoplastic Change. NCI Thesaurus. Code C20204.

Any alteration in cell state that promotes or renders a cell or cell population more vulnerable or prone to malignant conversion or transformation. $(\mathrm{NCl})$ 